\title{
THE AETIOLOGY OF ACUTE CERVICAL ADENITIS IN CHILDREN: SEROLOGICAL AND BACTERIOLOGICAL STUDIES
}

\author{
T. Yamauchi* $\dagger$, Patricia Ferrieri + AND B. F. Anthony* \\ * Department of Pediatrics, Harbor General Hospital, \\ UCLA School of Medicine, Torrance, California, \\ and the $\ddagger$ University of Minnesota Medical School, Minneapolis, \\ Minnesota, USA
}

\begin{abstract}
ACUTE cervical adenitis in children continues to be a common problem in paediatric medicine. The bacteria most commonly implicated have been group-A streptococci and Staphylococcus aureus. There is, however, some uncertainty in deciding which of these organisms is the primary pathogen causing cervical adenitis (Dajani, Garcia and Wolinsky, 1963; Scobie, 1969; Brook and Winter, 1971; Barton and Feigin, 1974; Wald and Sivasubramanian, 1976). Previous studies have demonstrated that the majority of staphylococci isolated in this illness are resistant to penicillin, although penicillin continues to be the drug of choice for group-A streptococcal infections (Breese, 1953; Goodman and Gilman, 1958; Stillerman et al., 1960; Breese, Disney and Talpey, 1965). This study was undertaken to determine the aetiology of acute cervical adenitis in children because successful antibiotic therapy depends on knowledge of the specific susceptibility of the organisms involved.
\end{abstract}

\section{MATERIAL AND METHODS}

The patients. The study population was selected from children 15 years of age or less who were seen in the Acute Care Clinic at Harbor General Hospital with a history of cervical mass of 72-h duration or less. During a 33-month period, 26 children met the criteria for admission to the study: (1) the presence of an anterior neck mass of at least $2 \mathrm{~cm}$ diameter which was tender and thought to be fluctuant, and (2) the absence of antibiotic therapy for the 2 weeks before the study. A detailed history and examination was performed and informed consent was obtained from the parent or guardian of every child. All children had the following laboratory studies: nose and throat cultures, intradermal skin tests with the equivalence of 5 tuberculin units of PPD-S, PPD-B, PPD-G and PPD-Y (with mycobacterial skin-test antigens provided by Dr Lydia Edwards of the United States Public Health Service), white blood-cell count, and erythrocyte sedimentation rate. In addition, many children had blood cultures, other intradermal skin tests (coccidiodin, histoplasmin, blastococcin and cat-scratch), chest roentgenogram, urinalysis and infectious mononucleosis slide test (Ortho Diagnostics Inc., Raritan, NJ, 08869).

After lymphnode aspiration, all children were treated with antibiotics for 7-10 days at the 
discretion of the house staff. Antibiotics used included: ampicillin $(75 \mathrm{mg} / \mathrm{kg}$ daily in four divided doses), cloxacillin ( $25-50 \mathrm{mg} / \mathrm{kg}$ daily in four divided doses) or penicillin (25-75 mg/kg daily in four divided doses). Two hospitalised children received methicillin $(100-150 \mathrm{mg} / \mathrm{kg}$ daily in four divided doses). Needle aspiration of the centre of a single mass, or the largest of several masses, was attempted on every child included in this study.

Needle aspiration and culture. After careful preparation of the overlying skin with iodine and alcohol and without anaesthesia, the node was entered with a sterile $1 \frac{1}{2}$-inch $(38 \mathrm{~mm})$ 20 -gauge needle attached to a sterile $10-\mathrm{ml}$ syringe. If material was not obtained, the needle was rinsed with thioglycollate broth which was inoculated onto plates of sheep blood, chocolate and Sabouraud's agar, into tubes of thioglycollate and brain-heart infusion broth, and onto Loewenstein-Jensen slants. Any aspiration material was examined by Gram's and acid-fast strains and inoculated as described above. In addition, six aspirates were cultured for anaerobic organisms with pre-reduced anaerobic media (Scott Laboratories). Group-A streptococci were tentatively identified with bacitracin discs (Hyland Laboratories). All coagulase-positive staphylococci were designated $S$. aureus. Antibiotic sensitivities were tested by the standardised disk method of Bauer et al. (1966). The node aspirates and throat swabs of several children were cultured for viruses on the following cell culture lines: HeLa, green-monkey kidney, human amnion, and WI-38 fibroblasts.

Serology. Acute and convalescent sera from 19 children were examined for antibodies to one or more streptococcal antigens. Antistreptolysin-O was measured by a modification of the micromethod of Edwards (1964), antideoxyribonuclease B (anti-DNAase B) by the method of Nelson, Ayoub and Wannamaker, 1968), and antinicotinamide adenine dinucleotidase (antiNADase) by the technique of Kellner, Freeman and Carlson (1958), as modified by Ayoub and Wannamaker (1962) and Ayoub and Ferretti (1966). Both serum samples from each patient were tested simultaneously. Single titres above 240 were considered elevated, and a significant rise in antibody titre was defined as two or more dilution increments in serial bleedings.

\section{RESULTS}

\section{Bacteriological studies}

The results of the bacteriological study of material obtained by needle aspiration of cervical lymph nodes are shown in table I. Only three of 26 lymph nodes were culture negative. S. aureus or group-A streptococci or both were isolated from $22(84.6 \%)$ of 26 nodes. S. aureus was isolated in pure culture from the lymph nodes of 17 children $(65.4 \%)$. Group-A streptococci were isolated as a single isolate in only four cases $(15.4 \%)$. One aspirate yielded $S$. aureus and group-A streptococci. Of the 18 staphylococcal isolates,

TABLE I

Bacteriological culture of needle aspirates from 26 cervical lymph nodes

\begin{tabular}{l|c}
\hline \multicolumn{1}{c|}{$\begin{array}{l}\text { Organism isolated } \\
\text { from lymph node }\end{array}$} & Number (\%) of cases \\
\hline $\begin{array}{l}\text { Staphylococcus aureus } \\
\text { Group-A streptococci }\end{array}$ & $17(65 \cdot 4)$ \\
$\begin{array}{l}\text { S. aureus and } \\
\text { group-A streptococci }\end{array}$ & $4(15 \cdot 4)$ \\
$\begin{array}{l}\text { Mycobacterium kansasii } \\
\text { No growth }\end{array}$ & $1(3 \cdot 8)$ \\
\hline Total & $3(11 \cdot 5)$ \\
\hline
\end{tabular}




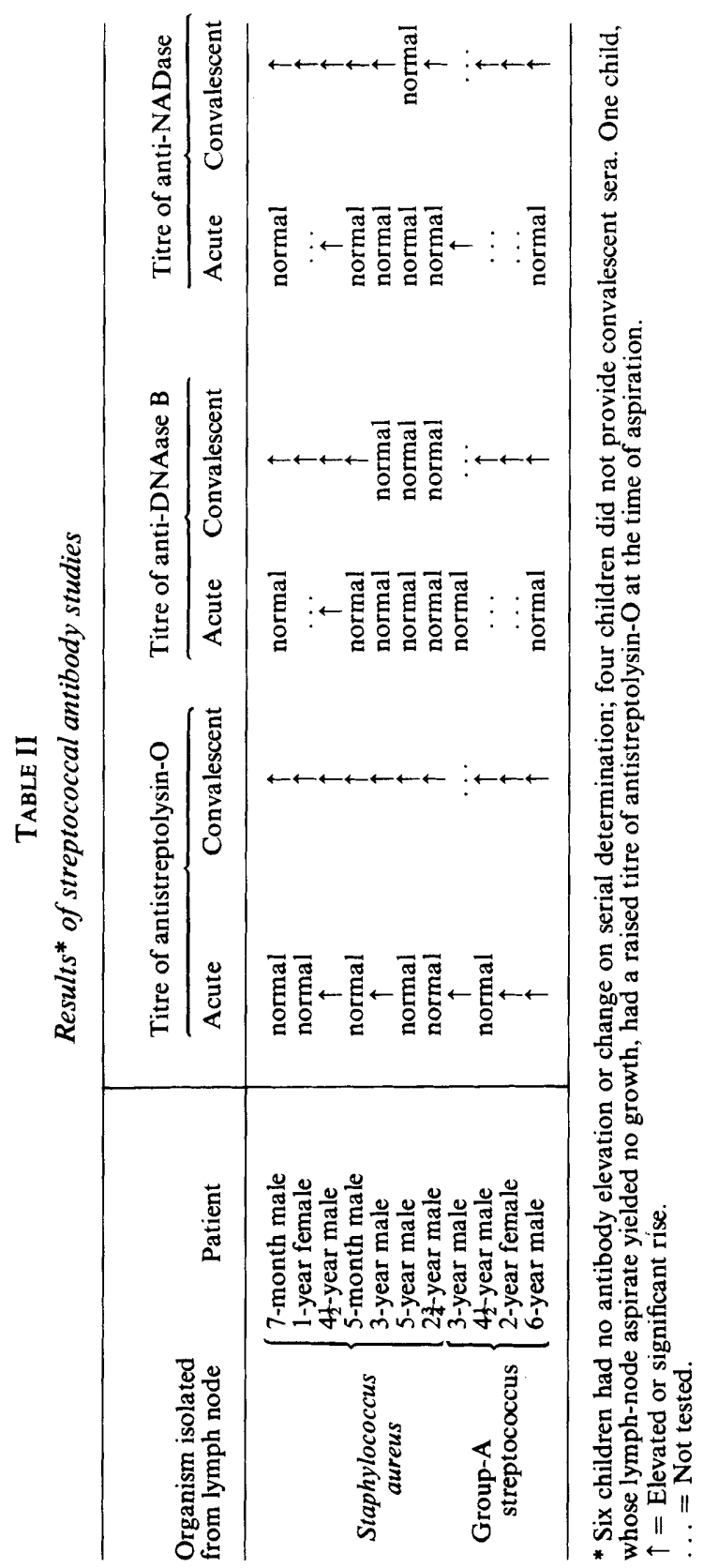


15 were resistant to penicillin. No anaerobic organism was isolated from the six aspirates studied. Mycobacterium kansasii was found in one aspirate. Gram-positive cocci were demonstrated in stained smears in $14(63.6 \%)$ of 22 lymph-node aspirates. Bacteria were always isolated by culture when organisms were seen on the stained smears. On several occasions, as expected, aspirates that failed to exhibit organisms by gram stain subsequently yielded organisms in culture. The atypical mycobacterium was initially demonstrated by acid-fast staining and was later obtained in culture. Only two of the 26 throat cultures yielded group-A streptococci. One of these children also yielded group-A streptococci from an infected lymph node and the other had $S$. aureus in the lymph-node aspirate.

\section{Virological studies}

Virus was isolated from the throat of two children in whom $S$. aureus was isolated from node aspirates, influenza A from one and respiratory syncytial virus from the other. Six node aspirates cultured for viruses were negative.

\section{Serological studies}

All four children whose nodes yielded only group-A streptococci had a significant elevation, or change on serial testing, of at least one of the streptococcal antibodies. It is of greater interest that seven of 17 patients with $S$. aureus in aspirates exhibited an immune response to one or more streptococcal antigens (table II); six others had no antibody elevation or change on serial determinations; convalescent sera were not obtained from the remaining four patients. Neither the child with mixed staphylococcal and streptococcal node isolates nor the child with atypical mycobacterial infection had elevated ASO titres at the time of aspiration. Additional sera for streptococcal antibodies were not obtained from either of these patients. Of the three patients with sterile node aspirates one had a streptococcal antibody response.

\section{Clinical findings}

The clinical findings in children with culture-proven S. aureus or streptococcal infections of lymph nodes were not different. Temperature, white blood-cell count and erythrocyte sedimentation rate were all elevated.

\section{Discussion}

Earlier studies on the pathogenesis of cervical adenitis in children indicated that group A-streptococci were the most commonly isolated organisms (Powers and Boisvert, 1944; Adamson, 1949; Dajani et al., 1963). More recently, clinical investigators have questioned the streptococcal aetiology of cervical adenitis in children. Scobie (1969) reviewed 946 cases of acute suppurative adenitis in children and attributed $67 \%$ to staphylococci. He con- 
cluded from these observations that the staphylococcus had replaced the streptococcus as the most common infecting organism causing inflammatory lymph-node disease. More recently, Barton and Feigin (1974), reported 76 cases of cervical adenitis, with $S$. aureus in $36 \%$ of lymph-node aspirates and only $25 \%$ attributable to streptococcal disease. In the studies of Scobie and of Barton and Feigin, prior antibiotic therapy had been given to some patients and neither study routinely sought serological evidence of streptococcal infection. In our report, 19 of the 26 children had serological studies in addition to culture of lymph-node aspirates. Because the ASO titre alone may not accurately reflect recent streptococcal infection, multiple serial antibody determinations were performed in most of our patients. The diagnostic value of streptococcal antibodies has been well defined in the literature (Stollerman $e t$ al., 1956; Kaplan et al., 1971; Bisno et al., 1973; Dillon and Reeves, 1974. Although in this series we report only four cases of pure group A-streptococcal culture from lymph nodes, all four children had either a significant elevation of streptococcal antibody initially, or a significant change of titre of one or more of the streptococcal antibodies during the course of treatment. More interestingly, although $S$. aureus was the only isolate in 17 cases $(65.6 \%)$, seven of these children (table II) had serological evidence of a recent streptococcal infection. Thus, by employing both bacteriological and serological criteria for establishing the aetiology of cervical adenitis we found that group-A streptococci were concerned in $13(50 \%)$ of the infections: four pure bacterial cultures, one mixed culture and eight positive by serology.

The recovery of influenza A from one child with cervical adenitis and respiratory syncytial virus from another raises the possibility that viruses may have a role in the aetiology of this disease. Several viruses have already been implicated in the pathogenesis of lymphadenopathy (Krugman, 1965; Debre and Celers, 1970; Henle and Henle, 1973). Although we were unable to isolate virus from several lymph-node aspirates, this remains an interesting area of speculation and needs further investigation. The majority of patients in this study were treated with penicillin or ampicillin (Krugman, 1965; Dillon and Reeves, 1974), and despite the high prevalence of penicillin-resistant staphylococci almost all children improved clinically with this therapy. This finding is consistent with the work of Markowitz and Dillon (Markowitz et al., 1965; Dillon, 1970), who reported uniformly effective treatment of streptococcal impetigo with penicillin despite the presence of penicillin-resistant staphylococci. An analogy can be made with the extensive epidemiological studies of nonbullous impetiginous lesions which suggest that although streptococci and staphylococci may coexist in lesions, the staphylococci play a subsidiary role as secondary invaders. Dajani et al. (1963) also reported isolation of penicillinresistant staphylococci alone and in combination with streptococci from patients with cervical adenitis and suggested that the staphylococcus was a co-invader.

It is difficult to determine the exact role of staphylococci in these cervical lymph-node infections. In this study, six children yielded $S$. aureus from their cervical lymph nodes and had no change of streptococcal antibody titre on 
serial determination. A reliable staphylococcal-antibody test would be useful in determining the significance of these cultures. One might speculate that the $S$. aureus was transported from the throat via lymphatics, thereby causing suppuration and infections of the lymph nodes. S. aureus has not, however, been related to tonsillitis-pharyngitis in the normal host. Moreover, the children in this study with staphylococcal disease, though few, did not have respiratory symptoms preceding their cervical adenitis. In contrast, the majority of children with streptococcal cervical lymph-node infections had respiratory symptoms.

By needle aspiration, culture and serial serological testing, we found that 13 $(50 \%)$ of the 26 cases in this report were associated with streptococci. In six of the children $S$. aureus was the only organism recovered and appeared to be the aetiological agent responsible for cervical lymph-node infections.

\section{SUMMARY}

Acute cervical adenitis was investigated in 26 children over a 33-month period. Lymph nodes were aspirated and cultured to yield Staphylococcus aureus or group-A streptococci or both from $22(84 \cdot 6 \%)$ of the aspirates. Mycobacterium kansasii was isolated from one child.

By combined culture and serial serological tests (antistreptolysin-O, antiDNAase B, and anti-NADase), $50 \%$ of the cases were found to be associated with streptococcal infection. In a few children, $S$. aureus was the only organism recovered, and appeared to be the aetiological agent.

This study was sponsored in part by Training Grant no. TolA100367 from the National Institute of Allergy and Infectious Disease, a General Research Support Grant to the Professional Staff Association; Harbor General Hospital, from the United States Public Health Service; and a research grant from the United States Public Health Service, AI09527. Dr Ferrieri was supported in part by grant no. HL06314-15 from the United States Public Health Service.

\section{REFERENCES}

ADAMson, C. A. 1949. Bacteriological study of lymph nodes: analysis of postmortem specimens with particular reference to clinical, serological and histopathological findings. Acta med. scand., 133 (suppl. 227), 1.

Ayoub, E. M. AND FerRetTI, J. J. 1966. Use of bisulfite in the streptococcal antinicotinamide adenine dinucleotidase test. Appl. Microbiol., 14, 391.

Ayoub, E. M. AND WanNamakeR, L. W. 1962. Evaluation of the streptococcal desoxyribonuclease $B$ and diphosphopyridine nucleotidase antibody tests in acute rheumatic fever and acute glomerulonephritis. Pediatrics., 29, 527.

Barton, L. L. and Feigin, R. D. 1974. Childhood cervical lymphadenitis: a reappraisal. $J$. Pediat., 84, 846.

Bauer, A. W., Kirby, W. M. M., Sherris, J. C. And Turck, M. 1966. Antibiotic susceptibility testing by a standardized single disc method. Am. J. clin. Path., 45, 493.

Bisno, A. L., Nelson, K. E., Waytz, P. and Brunt, J. 1973. Factors influencing serum antibody responses in streptococcal pyoderma. J. lab. clin. Med., 81, 410.

BREESE, B. B. 1953. Treatment of beta-hemolytic streptococcic infections in home: relative value of available methods. J. Am. med. Ass., 152, 10. 
Breese, B. B., Disney, F. A. and Talpey, W. B. 1965. Penicillin in streptococcal infections: total dose and frequency of administration. Am. J. Dis. Child., 110, 125.

Brook, A. H. AND Winter, G. B. 1971. Cervico-facial suppurative lymphadenitis due to staphylococcal infection in childhood. Br. J. oral Surg., 8, 257.

DaJANi, A. S., Garcia, R. E. AND Wolinsky, E. 1963. Etiology of cervical lymphadenitis in children. New Engl. J. Med. 268, 1329.

DEBRÉ, R. AND CELERS, J. 1970. Clinical virology: the evaluation and management of human viral infections. Saunders: Philadelphia, p. 322.

Dillon, H. C. 1970. The treatment of streptococcal skin infections. J. Pediat., 76, 676.

Dillon, H. C. AND ReEves, M. S. A. 1974. Streptococcal immune responses in nephritis after skin infection. Am. J. Med., 56, 333.

Edwards, E. A. 1964. Protocol for micro antistreptolysin O determinations. J. Bact., 87, 1254.

Goodman, L. S. And Gilman, A. 1955. Pharmacological basis of therapeutics, ed. 2, Macmillan: New York, p. 1307.

Henle, W. And Henle, G. 1973. Epstein-Barr virus and infectious mononucleosis. New Engl. J. Med., 288, 263.

Kaplan, E. L., Ferrieri, P. and Wannamaker, L. W. 1974. Comparison of the antibody response to streptococcal cellular and extracellular antigens in acute pharyngitis. $J$. Pediat., 84, 21.

Kaplan, E. L., Top, F. H., JR., Dudding, B. A. and Wannamaker, L. W. 1971. Diagnosis of streptococcal pharyngitis: differentiation of active infection from the carrier state in the symptomatic child. J. infect. Dis., 123, 490.

Kellner, A., Freeman, E. B. and Carlson, A. S. 1958. Neutralizing antibodies to streptococcal diphosphopyridine nucleotidase in the serum of experimental animals and human beings. J. exp. Med., 108, 299.

Krugman, S. 1965. Rubella: clinical and epidemiological aspects. Arch. ges. Virusforsch., 16, 477.

Markowitz, M., Bruton, H. D., Kuttner, A. G. and Cluff, L. E. 1965. The bacteriologic findings, streptococcal immune response, and renal complications in children with impetigo. Pediatrics., 35, 393.

Nelson, J., Ayoub, E. M. and Wannamaker, L. W. 1968. Streptococcal anti-desoxyribonuclease B: microtechnique determination. J. lab. clin. Med., 71, 867.

Powers, G. F. And Boisvert, P. L. 1944. Age as factor in streptococcosis. J. Pediat., 25, 481.

SCOBIE, W. G. 1969. Acute suppurative adenitis in children. A review of 964 cases. Scot. med. J., 14, 352.

Stillerman, M., Bernstein, S. H., Smith, M. L., Gittelson, S. B. and Karelitz, S. 1960. Antibiotics in the treatment of beta-hemolytic streptococcal pharyngitis: factors influencing the results. Pediatrics., 25, 27.

Stollerman, G. H., Lewis, A. J., Schultz, I. and Taranta, A. 1956. Relationship of the immune response to group A streptococci to the course of acute, chronic and recurrent rheumatic fever. Am. J. Med., 20, 163.

Wald, E. R., and Sivasubramanian, K. 1976. Cervical adenitis in infancy. Report of 4 cases due to staphylococci. Clin. Pediat., 15, 1168.

Zimmerman, R. A., Auernheimer, A. H. and Taranta, A. 1971. Precipitating antibody to group A streptococcal polysaccharide in humans. J. Immunol., 107, 832. 